\title{
Cinquième partie - Trafics et tarifs / Présentation
}

\author{
Maurice Wolkowitsch
}

\section{CpenEdition}

\section{Journals}

Édition électronique

URL : https://journals.openedition.org/rhcf/1427

DOI : 10.4000/rhcf.1427

Éditeur

Rails \& histoire

Édition imprimée

Date de publication : 10 février 2004

Pagination : 361

ISBN : 0996-9403

ISSN : 0996-9403

Référence électronique

Maurice Wolkowitsch, « Cinquième partie - Trafics et tarifs / Présentation », Revue d'histoire des chemins de fer [En ligne], 30 | 2004, mis en ligne le 17 août 2012, consulté le 22 avril 2022. URL : http:// journals.openedition.org/rhcf/1427 ; DOI : https://doi.org/10.4000/rhcf.1427

Ce document a été généré automatiquement le 22 avril 2022

Tous droits réservés 


\title{
Cinquième partie - Trafics et tarifs / Présentation
}

\author{
Maurice Wolkowitsch
}

1 Les compagnies de chemins de fer secondaires fonctionnent à une époque où le transport ferroviaire jouit d'un monopole, troublé par la concurrence de la voie d'eau, le long des parcours où elle était en mesure de s'exercer : l'acheminement vers les villes de céréales, des flux de pondéreux comme les matériaux de construction était attiré vers ce mode de transport économique. Mais les mouvements diffus de distribution de toutes sortes de marchandises dans le monde rural, essentiels pour l'activité des réseaux secondaires, échappaient à cette concurrence.

2 Les compagnies secondaires n'offraient ni aux voyageurs, ni aux chargeurs des conditions semblables à celles des grands réseaux; des obstacles techniques et les conditions d'exploitation s'y opposaient : domination de la voie métrique, qualité de la voie, signalisation, gabarit des matériels, voie unique, multiplication des arrêts, notamment facultatifs, et des passages à niveau non gardés, distances entre les points de croisement, tout concourait à réduire la vitesse et le débit des lignes.

3 Malgré ces faiblesses, ces petits chemins de fer ont tenu une place éminente dans l'éveil de la vie rurale; l'analyse de statistiques du trafic en fait foi. Cette constatation n'interdit pas une interrogation: ces compagnies ont-elles attendu le client, ont-elle éprouvé le besoin de stimuler le trafic, d'attirer la clientèle à travers des avantages tarifaires? C'est une question qu'on ne saurait éluder. 
INDEX

Mots-clés : aménagement du territoire, chemin de fer, exploitation ferroviaire, France, infrastructure ferroviaire, politique des transports/France, chemin de fer secondaire

\section{AUTEUR}

MAURICE WOLKOWITSCH

Professeur émérite à l'université de la Méditerranée 